\title{
Atypical Teratoid Rhabdoid Tumor in Childhood, 15 Cases of a Single Institute Experience
}

\section{Çocukluk Döneminde Atipik Teratoid Rabdoid Tümör, Tek Bir Merkezin 15 Olguluk Deneyimi}

\author{
Maysa AL-HUSSAINI', Noreen DISSI ', Usama AL-JUMAILY ${ }^{2}$, Maisa SWAIDAN ${ }^{3}$ \\ Departments of ${ }^{1}$ Pathology and Laboratory Medicine, ${ }^{2}$ Pediatric Oncology and ${ }^{3}$ Radiology, King Hussein Cancer Center, AMMAN, JORDAN
}

\begin{abstract}
Objective: Atypical teratoid rhabdoid tumor is a rare neoplasm with a distinct cytogenetic profile that predominates in infancy. Many cases show predominance of small cells with scanty rhabdoid cells, making recognition of this tumor difficult. We aim at describing our experience with atypical teratoid rhabdoid tumor cases diagnosed over a 6-year period.
\end{abstract}

Material and Method: Clinicopathologic features and immunohistochemical staining of atypical teratoid rhabdoid tumor cases diagnosed between 2006 and 2011 are presented.

Results: Fifteen cases were identified including 9 males with a median age of 26 months. The most common presenting symptom was recurrent vomiting with a mean duration of 6 weeks. Nine cases $(60 \%)$ were infratentorial and cerebrospinal fluid was positive in 2 cases $(13.3 \%)$ at time of diagnosis. The median overall survival of the group was 9.5 months. All cases except one showed admixture of rhabdoid and/or small round blue cells in variable proportions. Only 5 out of fourteen referred cases (35.7\%) were correctly diagnosed. Three cases showed unusual growth patterns. In 2 cases, nodular medulloblastoma-like growth pattern predominated, with loss of INI-1/BAF47 staining both within the nodules and the inter-nodular areas. The third case contained scattered individual and small groups of large cells with abundant acidophilic cytoplasm and eccentric nuclei, reminiscent of rhabdomyoblasts that were positive for GFAP and desmin, and retained nuclear staining for INI-1/BAF47, consistent with reactive gemistocytes.

Conclusion: Pathologists should be aware of the various, and unusual histopathologic patterns of atypical teratoid rhabdoid tumor. INI-1/ BAF47 immunostain should be performed on all central nervous system embryonal tumors, especially in infants and young children.

Key Words: Central nervous system neoplasms, Medulloblastoma, Immunohistochemistry
ÖZ

Amaç: Atipik teratoid rabdoid tümör çoğunlukla infantil dönemde görülen farklı sitogenetik profili olan nadir bir neoplazidir. $\mathrm{Bu}$ tümörün tanınmasını zorlaştıran durum, bir çok olguda seyrek rabdoid hücrelerle birlikte küçük hücrelerin baskın olmasıdır. Amacımız 6 yıllık bir sürede tanı alan atipik teratoid rabdoid tümör olgularıyla ilgili tecrübemizi sunmaktır.

Gereç ve Yöntem: 2006-2011 yılları arasında tanı alan atipik teratoid rabdoid tümör olgularının immünohistokimyasal ve klinikopatolojik bulguları sunulmuştur.

Bulgular: Ortalama yaşı 26 ay olan dokuzu erkek 15 olgu saptandı. En sık başvuru semptomu ortalama 6 hafta süren tekrarlayan kusmaydı. Dokuz olgu (\%60) infratentorial yerleşimlidir ve tanı sırasında iki olguda $(\% 13,3)$ beyin omurilik sivisı pozitifti. Grubun genel yaşam süresinin ortalaması 9,5 aydı. Bir olgu dışında tüm olgular küçük yuvarlak mavi hücreler ve/veya rabdoid hücrelerin değişik oranlarda karışımından oluşmaktaydı. Konsülte edilen 14 olgudan sadece beşinde $(\% 35,7)$ tanı doğru konmuștu. Üç olgu anormal gelișim paterni göstermekteydi. İki olguda hem nodüler hem de internodüler alanlarda INI-1/BAF47 boyanma kaybı ile birlikte nodüler medülloblastoma benzeri patern baskındı. Üçüncü olgu GFAP ve desmin pozitif olan tek tek ve gruplar halinde geniş eozinofilik sitoplazmalı ekzentrik nükleuslu rabdomyoblast benzeri büyük hücreler içermekte olup bu hücreler INI-1/BAF47 nükleer boyanması korunmuş olan reaktif gemisitosit ile uyumlu hücrelerdi.

Sonuç: Patologlar atipik teratoid rabdoid tümörün çeşitli ve olağan dışı histopatolojik paternlerinin farkında olmalıdırlar. İnfant ve küçük çocuklarda tüm santral sinir sistemi tümörlerinde INI-1/ BAF47 immünohistokimyasal boyası uygulanmalıdır.

Anahtar Sözcükler: Santral sinir sistemi tümörleri, Medulloblastom, İmmünohistokimya
(Turk Patoloji Derg 2014, 30:43-54)

Received : 07.10.2013 Accepted : 19.11.2013
Correspondence: Maysa AL-HUSSAINI

King Hussein Cancer Center, Department of Pathology and Laboratory Medicine, AMMAN, JORDAN

E-mail: mhussaini@khcc.jo Phone: +0096265300460 


\section{INTRODUCTION}

Atypical teratoid rhabdoid tumor (AT/RT) is a rare highly aggressive neoplasm of uncertain origin. It accounts for $1-2 \%$ of all brain tumors, and at least $10 \%$ of central nervous system (CNS) tumors in infants, with a slight male predominance (1). It occurs in supratentorial and infratentorial locations, but predominates infratentorially (2). Occasional examples can be multifocal (2) or originate within the ventricles (3). It was first described in 1987 as a tumor with a distinctive morphology characterized by proliferation of monomorphic cells with rhabdoid features hence was called malignant rhabdoid tumor of the central nervous system (4). Epithelial and mesenchymal elements were later recognized along with the frequent presence of the rhabdoid component, so the name was changed into "Atypical teratoid rhabdoid tumor" (5). The presence of a small cell component with the potential confusion with medulloblastoma and primitive neuroectodermal tumor (PNET) was appreciated later in several studies $(2,6)$. Eventually, in 1996 it was defined as a separate entity and was recognized in the 2000 WHO classification (7).

In 1999 AT/RT was linked to a highly specific genetic alteration i.e. the inactivation of hSNF5/INI-1 gene located on chromosome 22 (8). The introduction of an immunohistochemical antibody few years later that targets this mutation has resulted in the increasing recognition and reporting of this tumor (9). Recently however, Tsai et al. demonstrated that not all tumors with absence of INI1protein on immunostaining carry a mutation in the INI-1 gene, pointing towards other possible posttranscriptional regulatory mechanisms for INI-1 protein synthesis (10). AT/RT cases showing SMARCA4/BRG1 mutation have retained INI-1 expression (11).

The overall prognosis of AT/RT is dismal, and the reported median survival is less than one year (2). Separation of this tumor from mimickers including medulloblastoma and CNS-PNET is important due to the apparent poorer prognosis (12).

This study aims at summarizing our experience with cases of AT/RT diagnosed at the center over a 6-year period. Description of the clinical and pathological features is provided with emphasis on unique morphological patterns.

\section{MATERIAL and METHODS}

After obtaining the approval from the local institutional review board/research ethics committee, a retrospective search in the pathology files for cases diagnosed as AT/ RT over a six-year period (2006-2011) was performed.
Clinical data collected included age at presentation, gender, nationality, presenting symptoms and their duration, tumor location, radiological findings, presence or absence of cranio-spinal metastasis at time of diagnosis, modalities of treatment offered including surgery, chemotherapy (CTH) and radiotherapy (RTH), and date of last follow up. The outcome of patients was determined as dead versus alive at the last available follow up.

Pathologic material available from all cases was reviewed including hematoxylin-eosin (H\&E) slides, immunohistochemical stains, and cerebrospinal fluid slides. Pathologic features assessed included the growth patterns (diffuse, reticular, nodular, papillary), the types of cells present including rhabdoid cells (dyscohesive cells with vesicular nuclei, prominent nucleoli, and spherical cytoplasmic filamentous inclusions), pale cells (cells with vesicular nuclei, prominent nucleoli, and granular vacuolated wispy or water clear cytoplasm lacking intracytoplasmic inclusions), and small cells (small round blue cells with high nuclear to cytoplasmic ratio reminiscent of cells in medulloblastoma/PNET). The proportion of cell types was then assessed semi-quantitatively as focal or diffuse if occupying $<50 \%$ or $\geq 50 \%$ of the area of the slides examined; respectively. Moreover, the existence and the type of mesenchymal (myxoid, cartilaginous, lipomatous, osteoid, etc.) and epithelial (glandular, squamous, etc.) differentiation were determined. Finally necrosis and calcifications were also evaluated as present or absent. All immunohistochemical stains used are listed in Table I. Positive control was run for each antibody. Diffuse positive staining was defined as reactivity in $\geq 50 \%$ of tumor cells and otherwise the stain was considered focal.

All data were entered into an Excel sheet. Descriptive statistics including counts and percentages as well as medians and ranges were calculated for variables as applicable.

\section{RESULTS}

A total of fifteen cases were identified, 9 males and 6 females, with a male to female ratio of 1.5:1. The median age at diagnosis was 26 months (mean 28 months and range 6-61 months), with 7 (46.7\%) cases younger than 24 months. Nine (64\%) cases were Jordanian. The clinical symptoms were related to tumor location. The most common presenting symptoms were recurrent vomiting $(\mathrm{n}=11 ; 73.3 \%)$, squint $(n=4 ; 26.6 \%)$, unsteady gait $(n=3 ; 20 \%)$, and $6^{\text {th }}$ nerve palsy $(\mathrm{n}=2 ; 13.3 \%)$. The median duration of the symptoms was 6 weeks. The tumor was incidentally discovered in a single patient after a head trauma accident. One patient was the result of an in- vitro fertilization (IVF) pregnancy. 
Abdominal ultrasound was negative for renal masses in the patients investigated.

Nine $(60 \%)$ cases were located infratentorially and six (40\%) were supratentorial. In two cases the tumors were intraventricular occupying the $4^{\text {th }}$ and left lateral ventricles.

Initial magnetic resonance imaging (MRI) and/or computerized tomography (CT) scans were available for review in fourteen cases. In all cases the tumors were large, lobulated and heterogeneous. They showed contrast enhancement $(n=10 ; 71.4 \%)$, a partially cystic appearance $(n=9 ; 64.3 \%)$, mild edema ( $n=6 ; 46.8 \%)$, and calcifications $(n=4 ; 28.5 \%)$. Cranio-spinal metastases were present at the time of diagnosis in $2(14.3 \%)$ cases and developed later during the course of the disease in an additional $5(35.7 \%)$.

In the cases with available data on the extent of surgical resection, gross total resection (GTR) was performed in 5 (38.5\%), subtotal resection (STR) in $3(23.0 \%)$, and partial resection (PR) in $5(38.5 \%)$. The extent of resection was not documented in two (13.3\%) cases. Chemotherapy (CTH) was offered to $10(66.6 \%)$ cases, including four who also received radiotherapy (RTH), while RTH alone was offered for a single $(7.1 \%)$ case. No documented further treatment was offered to the 4 remaining cases.

At time of data collection, eleven of twelve (91.7\%) cases with available follow up data were dead of local and/ or disseminated disease. One case was still alive without evidence of disease 86 months following diagnosis. The median progression free survival and overall survival were less than a year being 7.75 months and 9.5 months, respectively.

Table II summarizes the patients' demographics, clinical findings and outcome.

\section{Pathologic and Immunohistochemical Findings:}

Table III summarizes the morphological and immunohistochemical characteristics of tumors.

Growth pattern was predominantly diffuse in nine cases $(60 \%)$ with nodular, reticular and papillary patterns noted in 2 cases each (13.3\%). Common cellular components included rhabdoid cells $(\mathrm{n}=12 ; 80.0 \%$ ) (Figure 1A), large pale cells $(n=12 ; 80.0 \%)$ and small round blue cells $(n=13 ; 86.6 \%)$ (Figure 1B). Admixture of all the three cell components was noted in most cases $(n=9 ; 60 \%)$. None of the fifteen cases examined was composed exclusively of rhabdoid cells. On the contrary small cells were the only cells identified in a single case and were diffusely identified in 2 (13.3\%) other cases. Variable mesenchymal components were recognized focally including myxoid/fibromyxoid changes in six cases, while chondroid (Figure 1C), lipoblastic (Figure 1D) and spindle cells elements were noted in a single case each. No glandular component was seen in any of the cases, although

Table I: List of immunohistochemical antibodies used

\begin{tabular}{|l|c|c|c|c|}
\hline Antibody & Clone & Dilution & Pretreatment & Vendor \\
\hline INI-1/BAF47 & $25 /$ BAF47 & 1 to 50 & Heat (CC1) 30 minutes & BD \\
\hline EMA & E29 & Ready to use & Heat (CC1) 60 minutes & Ventana \\
\hline PAN-CK & AE1/AE3PCK26 & Ready to use & protease 1 for 4 minutes & Ventana \\
\hline CK 8-18 & B22.1\&B23.1 & Ready to use & Protease 1 for 8 minutes & Ventana \\
\hline Synaptophysin & Polyclonal & Ready to use & Heat (CC1) 30 minutes & Ventana \\
\hline Chromogranin A & LK2H10 & Ready to use & Heat (CC1) 30 minutes & Ventana \\
\hline GFAP & EP672Y & Ready to use & Heat (CC1) 30 minutes & Ventana \\
\hline Vimentin & V9 & Ready to use & Heat (CC1) 60 minutes & Ventana \\
\hline Smooth Muscle Actin & 1 A4 & Ready to use & Heat (CC1) 60 minutes & Ventana \\
\hline Desmin & DE-R-11 & Ready to use & Protease 1 for 8 minutes & Ventana \\
\hline CD99 & MIC2 & 1 to 50 & Heat (CC1) 60 minutes & BioGenex \\
\hline PGP(P) & Polyclonal & 1 to 200 & Heat (CC1) 30 minutes & Cell Marque \\
\hline CD45(LCA) & 2 B-11\&PD7126 & Ready to use & Heat (CC1) 30 minutes & Ventana \\
\hline PLAP & NB10 & Ready to use & Heat (CC1) 30 minutes & Ventana \\
\hline Myogenin & F5D & Ready to use & Heat (CC1) 60 minutes & Ventana \\
\hline Transthyretin & Polyclonal & 1 to 100 & Heat (CC1) 60 minutes & Dako \\
\hline Ki67 & k-2 & Ready to use & Heat (CC1) 60 minutes & Ventana \\
\hline
\end{tabular}


Table II: Patient's demographics, clinical and radiological features and outcome

\begin{tabular}{|c|c|c|c|c|c|c|c|c|c|c|c|}
\hline $\begin{array}{l}\text { Case } \\
\text { No. }\end{array}$ & Sex & $\begin{array}{c}\text { Age/ } \\
\text { Months }\end{array}$ & $\begin{array}{l}\text { Symptoms } \\
\text { /Weeks }\end{array}$ & Location & Referral Diagnosis & $\begin{array}{c}\text { CS } \\
\text { Mets }\end{array}$ & Surg & CTH & RTH & Status & $\begin{array}{c}\text { OS/ } \\
\text { Months }\end{array}$ \\
\hline 1 & $\mathrm{M}$ & 26 & 16 & Cerebellum & MB & - & GTR & + & + & $\begin{array}{l}\text { Alive } \\
\text { NED }\end{array}$ & 86 \\
\hline 2 & $\mathrm{M}$ & 22 & 4 & Left fronto-parietal & $\mathrm{AE}$ & - & GTR & - & - & Lost FU & 1 \\
\hline 3 & $\mathrm{M}$ & 45 & 3 & Left lateral ventricle & $\begin{array}{c}\mathrm{MB} / \mathrm{PNET} / \\
\text { ependymoblastoma }\end{array}$ & + & PR & + & + & Dead & 14 \\
\hline 4 & $\mathrm{~F}$ & 6 & 2 & Posterior fossa ${ }^{\star *}$ & ND & ND & ND & - & - & Lost FU & NA \\
\hline 5 & $\mathrm{M}$ & 15 & 32 & Left temporal & AE/PNET & + & GTR & + & + & Lost FU & 8 \\
\hline 6 & $\mathrm{M}$ & 61 & 8 & Left temporal & AT/RT & - & GTR & + & + & Dead & 33 \\
\hline 7 & $\mathrm{~F}$ & 29 & 24 & Cerebellum & MB & + & PR & + & - & Dead & 25 \\
\hline 8 & $\mathrm{M}$ & 26 & $0^{*}$ & Cerebellum & $\mathrm{MB}$ & + & $\mathrm{PR}$ & - & - & Dead & 11 \\
\hline 9 & $\mathrm{~F}$ & 56 & 12 & Cerebellum & MB/ependymoma & + & ND & - & + & Dead & 7 \\
\hline 10 & $\mathrm{~F}$ & 12 & 3 & Cerebellum & $\mathrm{MB}$ & + & $\mathrm{PR}$ & + & - & Dead & 6 \\
\hline 11 & $\mathrm{M}$ & 13 & 2 & $\begin{array}{l}\text { Right tempor- } \\
\text { parietal }\end{array}$ & AT/RT & + & STR & + & - & Dead & 9 \\
\hline 12 & $\mathrm{~F}$ & 14 & 8 & Left CPA & AT/RT & - & STR & + & - & Dead & 7 \\
\hline 13 & $\mathrm{~F}$ & 60 & 2 & Left fronto-parietal & AT/RT & - & STR & + & - & Dead & 6 \\
\hline 14 & $\mathrm{M}$ & 9 & 6 & Cerebellum & MB & - & $\mathrm{PR}$ & + & - & Dead & 10 \\
\hline 15 & $\mathrm{M}$ & 28 & 6 & $4^{\text {th }}$ ventricle & $\mathrm{AT} / \mathrm{RT}$ & - & GTR & - & - & Dead & 11 \\
\hline
\end{tabular}

M; male, F; female, CPA: cerebello-pontine angle, CS; cranio-spinal, Mets; metastasis, MB; medulloblastoma, AE; anaplastic ependymoma, PNET; primitive neuroectodermal tumor, ND; not documented, Surg; surgery, GTR; gross total resection, PR; partial resection, STR; subtotal resection, CTH; chemotherapy, RTH; radiotherapy, NED; no evidence of disease, FU; follow up, *; Incidental discovery after head trauma following falling down. ${ }^{* *}$; Radiology was not available for proper evaluation of the exact origin of the tumor.

Table III: Morphological and immunohistochemical characteristics of tumors

\begin{tabular}{|c|c|c|c|c|c|c|c|c|c|c|c|c|c|}
\hline $\begin{array}{c}\text { Case } \\
\text { No. }\end{array}$ & $\begin{array}{c}\text { Growth } \\
\text { Pattern }\end{array}$ & $\mathbf{R C}$ & $\mathbf{P C}$ & SC & EC & MC & Calc & EMA & Syn & GFAP & Vimentin & SMA & CK \\
\hline 1 & Diffuse & + & + & + & - & - & - & Diffuse & Diffuse & Focal & NA & NA & Diffuse \\
\hline 2 & Papillary & + & + & - & + & Spindle & - & Focal & Focal & Focal & Diffuse & Focal & - \\
\hline 3 & Reticular & - & + & + & - & Myxoid & + & Focal & Focal & Focal & Diffuse & Focal & NA \\
\hline 4 & Diffuse & + & + & + & - & Myxoid & - & NA & NA & NA & NA & NA & NA \\
\hline 5 & Diffuse & + & + & + & - & - & + & Diffuse & Diffuse & Diffuse & Diffuse & NA & - \\
\hline 6 & Diffuse & + & + & + & - & - & - & - & Focal & - & Diffuse & - & Focal \\
\hline 7 & Nodular & + & + & + & - & - & - & Focal & Focal & NA & Diffuse & NA & NA \\
\hline 8 & Nodular & + & - & + & - & - & - & NA & Focal & - & NA & NA & NA \\
\hline 9 & Diffuse & + & + & + & - & Myxoid & - & Focal & - & Diffuse & NA & NA & Focal \\
\hline 10 & Diffuse & - & - & + & - & Myxoid & - & Focal & Focal & Focal & NA & NA & - \\
\hline 11 & $\begin{array}{c}\text { Reticular, } \\
\text { cords }\end{array}$ & - & + & - & - & $\begin{array}{c}\text { Chondroid, } \\
\text { fibromyxoid }\end{array}$ & - & Focal & Focal & NA & NA & NA & NA \\
\hline 12 & Diffuse & + & - & + & - & - & - & Focal & NA & NA & NA & NA & Focal \\
\hline 13 & Diffuse & + & + & + & - & - & + & Focal & NA & - & NA & NA & - \\
\hline 14 & Papillary & + & + & + & + & Myxoid & - & Diffuse & NA & Focal & NA & NA & Diffuse \\
\hline 15 & Diffuse & + & + & + & - & Lipoblast- like & - & Diffuse & Focal & Focal & NA & Focal & Diffuse \\
\hline
\end{tabular}

RC; rhabdoid cells, PC; pale cells, SC; small cells, EC; epithelial component, MC; mesenchymal component, Calc; calcification, CK; cytokeratin, EMA; epithelial membrane antigen, NA; not applicable, GFAP; glial fibrillary acidic protein, Syn; synaptophysin, SMA; smooth muscle actin. 
papillary structures were seen in two (13.3\%) (Figure 1E). Necrosis was evident in all (100\%) cases, while dystrophic calcifications were noted in three (20\%).

Cerebrospinal fluid analysis was performed at presentation in ten out of fifteen cases. Malignant cells were identified in $2(20 \%)$, both with positive leptomeningeal seeding by MRI studies. Cytologically, the smears showed clusters and individual large cells with abundant eosinophilic cytoplasm and eccentric nuclei (Figure 1F).

The diagnosis of AT/RT was confirmed in all cases through demonstrating total loss of INI-1/BAF47 nuclear immunostain in all kinds of tumor cells present in all cases with appropriate positive normal endothelial and mononuclear cell control in the examined slides (Figure 2A). Where available rhabdoid and non- rhabdoid cells showed variable positivity for EMA in twelve of thirteen cases (Figure 2B), being diffusely positive in four (33.3\%). Synaptophysin displayed positivity in all ten cases examined, being diffusely positivity in two (20\%) (Figure 2C). Eight out of eight cases stained for glial fibrillary acidic protein (GFAP), being diffuse in two (18.1\%) (Figure 2D). Vimentin was diffusely positive in five of five cases (100\%). Smooth muscle actin (SMA) was only focally positive in three of four cases (75\%) (Figure 2E) and pan-cytokeratin was positive in six out of ten cases, being diffusely positive



Figure 1: A) Rhabdoid dyscohesive cells with vesicular nuclei, prominent nucleoli, and spherical cytoplasmic filamentous inclusions (H\&E, x200). B) Small hyperchromatic cells similar to PNET/medulloblastoma showing dense nuclei, dispersed chromatin, small to inconspicuous nucleoli, with scant cytoplasm and indistinct cell borders, arranged in a solid pattern (H\&E x200). C) Areas of chondroid differentiation arranged in a reticular and cord like patterns (H\&E x200). D) Lipoblastic-like cells with clear vacuolated cytoplasm and eccentric nuclei (H\&E x200). E) AT/RT displaying an epithelial component with a papillary architecture (H\&E x200). F) CSF smear displaying a single tumor aggregate with rhabdoid features (Diff Quick stain x200). 
in three (50\%) (Figure 2F). Desmin ( $\mathrm{n}=4), \operatorname{CD} 99(\mathrm{n}=3)$, and transthyretin $(n=2)$, were all negative. The Ki67 labelling index ranged between $30-50 \%$.

\section{Cases with distinct morphological patterns}

In two cases (cases number 7 and 8), a nodular medulloblastoma-like growth pattern predominated. There were pale nodules with distinct neuropil containing slightly mature cells lacking mitosis (Figure 3A). The inter-nodular areas showed a more compact proliferation of small round blue cells. In both cases scattered rhabdoid cells were noted after a more meticulous search. Synaptophysin (Figure 3B) was focally positive inside the nodules in both cases while chromogranin (Figure 3C) was only focally weakly positive inside the nodules in a single case. Reticulin stain was negative in both cases with no evidence of desmoplasia. Focal positivity for epithelial membrane antigen (EMA) (Figure 3D) and diffuse positivity for vimentin in the internodular but not the intra-nodular areas (Figure 3E) was noted in one of the cases. However the total absence of INI1/BAF47 immune-expression was seen in both the intra and inter-nodular areas (Figure 3F) in both cases. Both cases developed leptomeningeal metastases, and died of disease progression 25 and 11 months after the initial diagnosis.

A single case (case number 6) harboured many single and small aggregates of large cells with abundant acidophilic cytoplasm that were closely related to the blood vessels (Figure 4A). These cells were strongly positive for GFAP (Figure 4B), vimentin and desmin (Figure 4C), but were

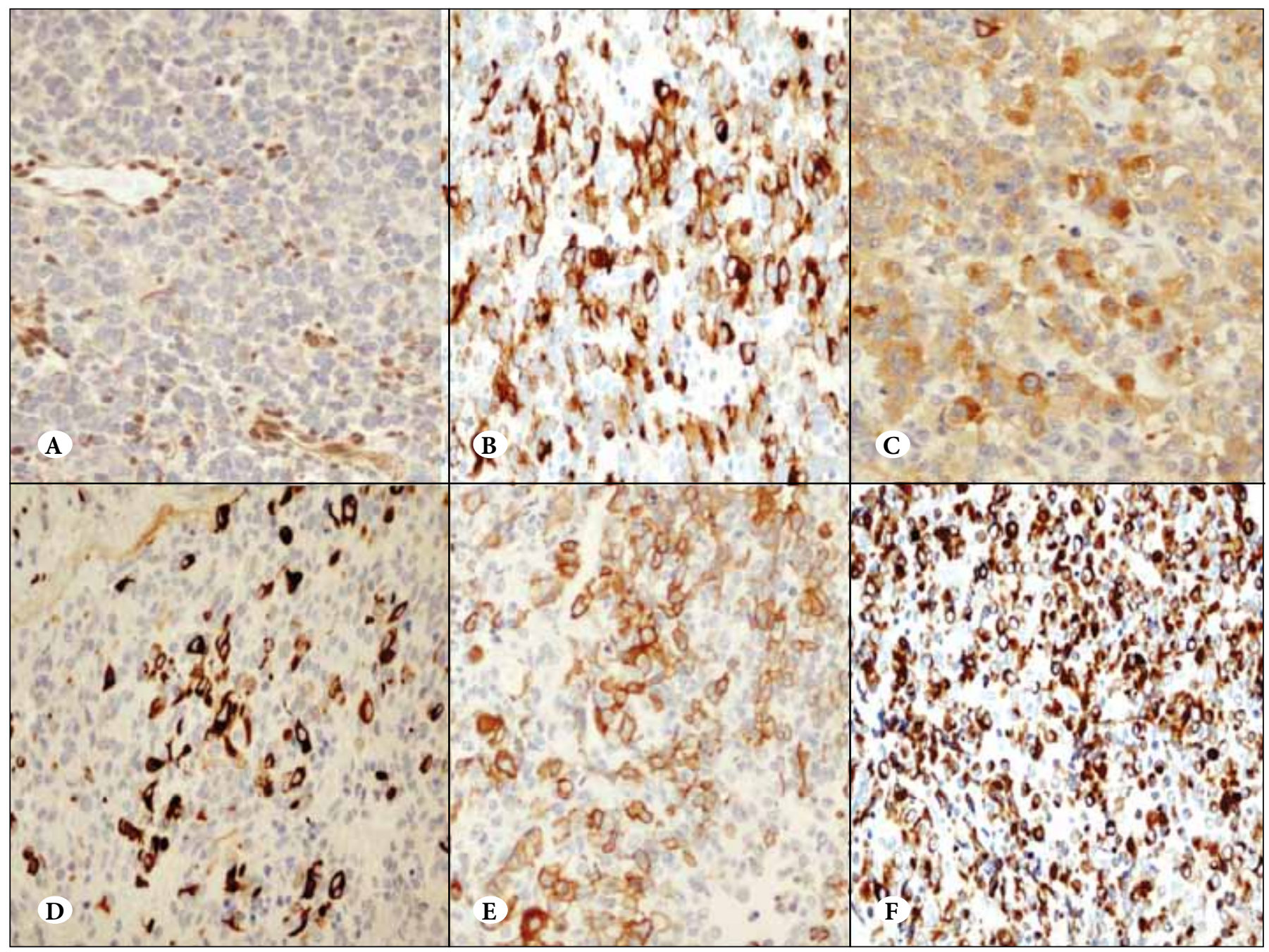

Figure 2: The variable immunostaining profile for AT/RT. A) INI-1/BAF47 immunostain is lost in tumor cells nuclei, but is retained in the endothelial cells. B) EMA shows strong positivity in tumor cells. C) Synaptophysin is diffusely moderately to strongly positive in tumor cells. D) GFAP shows focal strong positivity. E) Smooth muscle actin is diffusely weakly positive and F) pan-cytokeratin (MNF) is diffusely strongly positive. (All stains are using 20 objective: $\mathrm{x} 200$ ). 
negative for myogenin (not shown) and smooth muscle actin (Figure 4D) ruling out the possibility of rhabdomyoblastic and smooth muscle differentiation, respectively. Although the tumor cells were focally positive for pan-cytokeratin the large cells were negative (Figure $4 \mathrm{E}$ ), and they retained nuclear stain for INI-1/BAF47 (Figure 4F) against the negative tumor cells. They were consistent with aggregates of reactive gemistocytic astrocytes.

\section{Referral cases}

All cases were initially operated on and diagnosed outside our center. The original diagnosis was not documented in a single case. In five (35.7\%) cases the diagnosis was consistent with AT/RT and nine (64.3\%) discordant cases were identified, as listed in Table II. The most frequent diagnosis assigned by the original pathologists was medulloblastoma $(\mathrm{n}=7 ; 77.7 \%)$ and anaplastic ependymoma $(\mathrm{n}=2 ; 22.2 \%)$. Both cases with nodular medulloblastoma-like growth pattern were misdiagnosed as medulloblastoma. INI-1/ BAF47 was not ordered on any of the discordant cases, while it was performed on all concordant ones. Notably; the percentage of discordant cases decreased after 2010. Four out of the 7 (57.1\%) referral cases were correctly diagnosed as AT/RT since 2010, versus $1 / 7(14.3 \%)$ cases diagnosed before 2010 .

\section{Long term survival case}

A single long-term survival was identified (case number

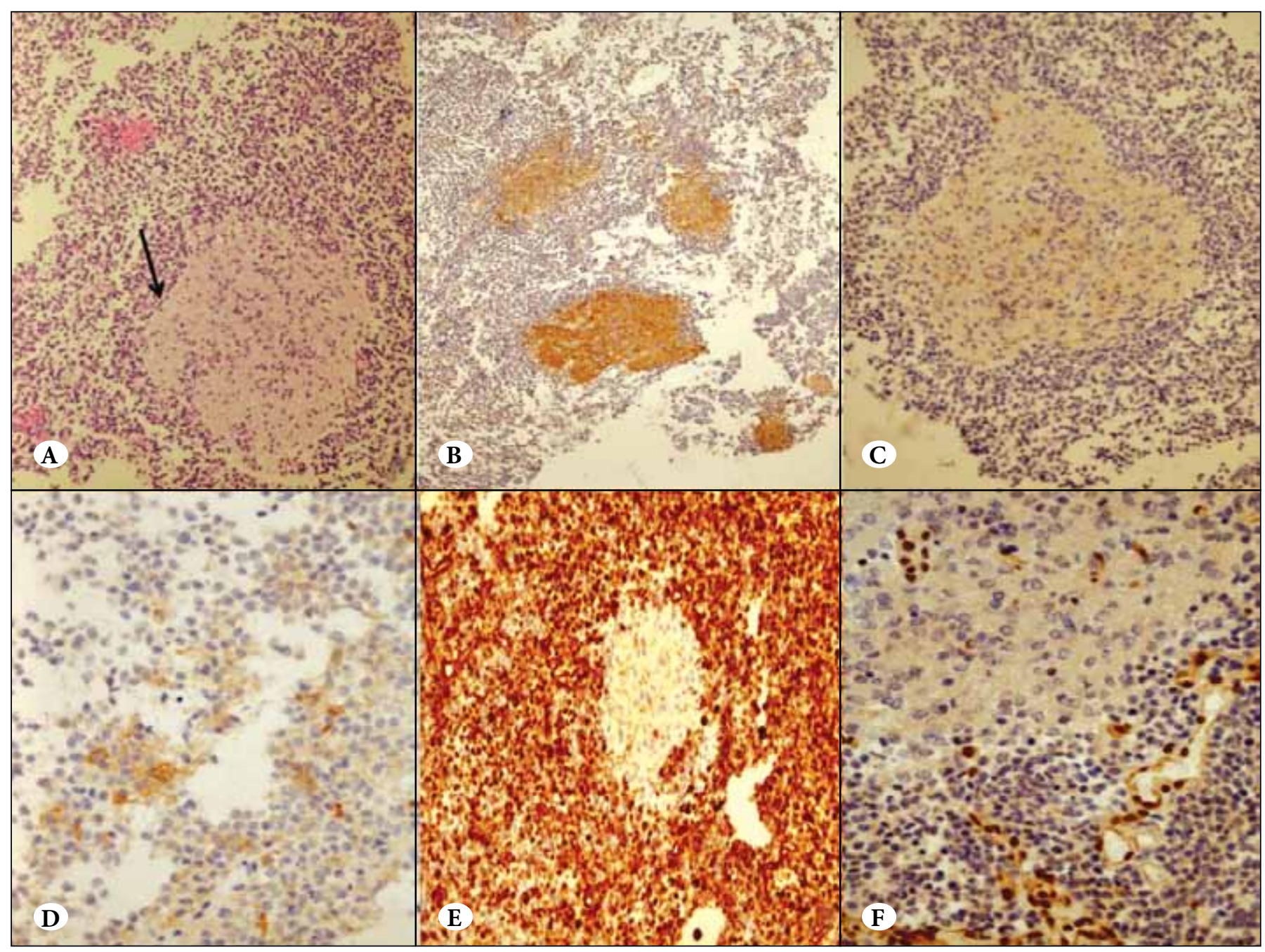

Figure 3: AT/RT mimicking nodular medulloblastoma. A) Small undifferentiated cells with pale islands showing marked neuronal differentiation (arrow, H\&E x200). B) Synaptophysin is positive in areas of neuronal differentiation (Synaptophysin x200). C)Chromogranin is weakly positive in the same areas (Chromogranin x200). D) EMA is focally positive (EMA x200). E) Vimentin is negative in the differentiated pale areas and positive in the inter-nodular cellular areas (Vimentin x200). F) Loss of INI-1 nuclear staining is visible in both inter- and intra-nodular areas with appropriate positive control of endothelial cells (INI-1/BAF47 x200), excluding the possibility of entrapped normal nodular parenchyma. 


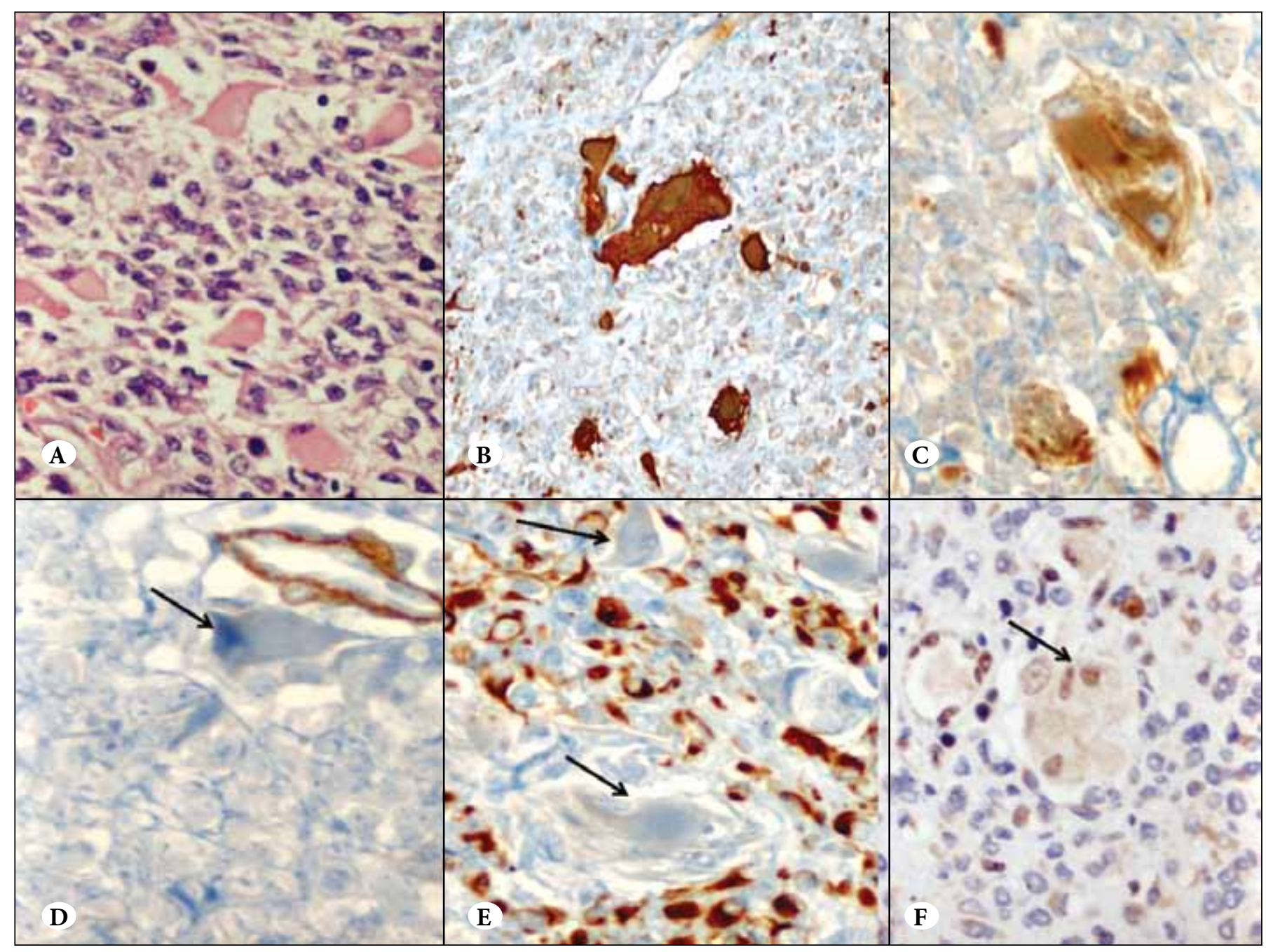

Figure 4: Small aggregates of reactive gemistocytes in a case of AT/RT. A) Gemistocytic-like cells showing abundant glassy eosinophilic cytoplasm, eccentric vesicular nuclei, and small prominent nucleoli, arranged predominantly around blood vessels (H\&E x400). B) GFAP is strongly positive in these cells (GFAP x200). C) Desmin is positive (Desmin x400), D) whereas smooth muscle actin is negative (arrow points at one of the cells, SMA x400). E)They were negative for cytokeratin, although the surrounding tumor cells were positive (arrows point at the cells, CK x200). F) INI-1/BAF47 nuclear stain is retained in these cells (arrow) confirming that they are not an integral part of the tumor (INI-1/BAF47 x400).

1). This patient presented initially at age of 23 months to another institution with unsteady gait, vomiting and squint of 16 weeks duration. Physical examination at diagnosis was unremarkable. Brain imaging showed a lobulated, complex partly solid partly cystic mass lesion involving the left cerebellar hemisphere and the vermis. It measured about $3.8 \times 4.3 \mathrm{~cm}$ and showed extension into the $4^{\text {th }}$ ventricle. It also extended through the left foramen of Luscka. He underwent GTR, with ventriculo-peritoneal (VP) shunt insertion. The referral diagnosis was medulloblastoma. At our institution, the case was diagnosed as AT/RT on the basis of total loss of INI-1/BAF47 immunostain in the tumor cells. Cerebrospinal fluid (CSF) cytology, bone marrow examination and abdominal ultra-sound for renal tumors were all negative. He was started on chemotherapy and received cranio-spinal irradiation of 180 grays/28 sessions. He is now 9 years and 5 months old with no evidence of disease 86 months after diagnosis.

\section{DISCUSSION}

We have summarized our experience with AT/RT cases diagnosed and managed at our center. The findings are at large compatible with the international literature $(13,14)$. Our patients had a median age of 26 months at presentation, a predominance of males with sixty percent occurring in the posterior fossa. A single case was the product of IVF, 
(case number 7), who presented at 29 months of age, a rarely reported association (15).

Radiologically findings are at large non-specific. The tumors are usually non homogeneous secondary to the heterogeneous cellular populations as well as the frequent presence of necrosis and hemorrhage. Nine of our cases contained a cystic component which is higher than the occasional eccentric cyst formation described in some reports (16). In contrast to medulloblastoma (MB), infratentorial AT/RT tend more often to be extra-axial involving the cerebello-pontine (CP) angle, and to be associated with intra-tumoral hemorrhage, which might help in suggesting the diagnosis radiologically (17). One of our cases originated in the left $\mathrm{CP}$ angle and was one of the five cases with concordant referral diagnosis. More recently; the MR-based apparent diffusion coefficient histogram was able to separate all cases of supratentorial PNET from AT/ RT cases (18). Pure intra-ventricular examples included 2 cases in the left lateral and $4^{\text {th }}$ ventricles, a rare but well documented origin of AT/RT. In the original article by Meyers S.P on 17 cases a single case of intraventricular tumor involving the septum pellucidum was reported (3), while Donovan et al. reported a midline lateral ventricular tumor which presented with intra-ventricular hemorrhage (19). None of our intra-ventricular cases presented with hemorrhage. A fourth ventricular origin of AT/RT has been reported by Inenega $\mathrm{C}$ et al. in an infant with a dismal outcome (20). The outcome in both of our cases was poor and did not differ from the rest of patients despite of GTR of the $4^{\text {th }}$ ventricular tumor. The intra-ventricular origin of a small subset of AT/RT cases brings choroid plexus carcinoma (CPC) into the differential diagnosis, especially that both tumors share predominance in infancy and young children. Immunostaining reveals epithelial markers, especially cytokeratin and less frequently EMA, to be positive in CPC. Other less frequent positive markers include synaptophysin and GFAP. INI-1/BAF 47 has been described in cases of choroid plexus carcinoma (21)f. This has led to the speculation that AT/RT and CPC might be related tumors especially that the origin of AT/RT is not yet resolved. A finding that has been recently supported by evidence of choroid plexus epithelial differentiation in 2 AT/RT cases exhibiting membranous staining by Kir7.1 (22). However; we believe that our cases are AT/RT rather than CPC due to the immature/PNET like nature of the tumor cells, the presence of myxoid/mesenchymal features, the absence of papillae, eosinophilic globules, as well as the diffuse absence of INI-1/BAF 47 immunostain despite of the positive staining for cytokeratin in one of the tumors.
None of our tumors was predominantly composed of rhabdoid cells. On the contrary; small round blue cells component was seen in $86.6 \%$ of our cases and was the only component in a single case and the predominant component in 2 others. This finding is well described in literature with a more aggressive behavior than other primitive tumors $(12,23)$. In addition; various mesenchymal components can be seen including chondroid, myxoid and spindle cell sarcoma, which can occasionally predominate (24). Epithelial components in the form of papillary structures, cohesive cell nests, tubule-glandular patterns and keratinizing squamous islands have all been previously reported (25). This variable cellular and tissue patterns are reflected in the variable immunostaining profile of AT/ RT (26). Loss of INI-1 expression from tumor cell nuclei remains currently the best available stain forming the basis of the diagnosis of AT/RT in most cases. Caution should be experienced in misinterpretation of irrelevant cytoplasmic brush staining as positive staining. Also pathologists should be aware of the occasional cases of AT/RT with retained nuclear staining (27). Staining for other markers including insulin-like growth factor II, insulin-like growth factor receptor type I, and cathepsin have been reported (28). Interestingly; the embryonal/germ cell tumor marker SALL4 has been recently described in cases of AT/RT(29). Immune-expression of claudin- 6 has been proposed as a specific positive diagnostic marker (30), which was linked to poor prognosis in some $(23,27)$ but not all studies $(31$, 32). The divergent differentiation characteristic of AT/RT has been attributed by some to the presence of CD133+ stem cells (33).

Two unusual morphological patterns were encountered in three of our cases carrying a potential for misdiagnosis. AT/ RT mimicking nodular medulloblastoma was reported by Varlet el al (34). This was further confirmed at the somatic level by detection of hemizygous deletion of the whole hSNF5/INI-1 gene and point mutations in exon 2 of the remaining allele. Haberler et al. described pale nodules in one of their cases at post mortem examination. Unlike our cases however, these nodules consisted of rhabdoid cells on high power examination and did not show neuropil or neuronal differentiation (12).

The reactive gemistocytes in the third case exhibited abundant acidophilic cytoplasm, and together with the unexpected positivity for desmin brought resemblance to rhabdomyoblasts. A case with similar findings was reported by Fleming et al., which was initially misdiagnosed as gliosarcoma (23). Positivity for desmin in CNS tumors should be interpreted with caution as certain clones 
particularly DE-R-11 is reported to show cross immunereactivity in normal and tumor astrocytes (35).

AT/RT is gaining more recognition by the reporting pathologists over the last few years. Many of our cases were initially misdiagnosed as other tumors, especially medulloblastoma. Although at least focal rhabdoid cells were seen on review in all but one case, these cells were overlooked by the initial reporting pathologist. In addition, INI-1 /BAF47 was not performed on most of the cases prior to referral, since AT/RT was not suspected. In their series on 12 cases Fleming et al. recognized retrospectively 10 cases (23), while Woehner et al. on their review of Austrian Brain Tumor Registry identified $52.6 \%$ cases that were retrospectively diagnosed as AT/RT (36). In our series the number of correctly diagnosed referrals of AT/RT increased since 2010 , probably a reflection of the growing recognition of the entity.

It is possible that inactivation of INI-1 may be associated with a poor prognosis, even if the rhabdoid component of the tumor is not apparent by histological or immunohistochemical studies (8). However; this has been recently challenged with the description of a new entity, cribriform neuroepithelial tumor (CRINET), which despite of showing loss of INI-1 / BAF47 immunostain, it carries a relatively favourable prognosis (37).

The lack of therapeutic response and dismal prognosis necessitates separating AT/RT from other CNS embryonal tumors including CNS-PNET, medulloblastoma, ependymoma and others (38), especially in infants and children younger than 3 years of age at diagnosis and children with metastatic disease (39). The use of aggressive therapy modalities including a combination of surgery, chemotherapy with or without stem cell rescue, intra-thecal chemotherapy and radiotherapy has resulted in some improvement in the natural history of the tumor (40). Gross total resection including a second look surgery is the strongest factor associated with survival $(13,14)$. The only long-term survival in our series underwent GTR. However; all other 4 patients with GTR have died as a result of the disease suggesting that other factors are linked to outcome. The use of Head-Start-I (HS I), which is the standard modality of treatment at our center, or Head- Start-II (HS II) regimens, has resulted in long-term survivors of up to 67 months following diagnosis (41). Intra-thecal chemotherapy seems to decrease the risk of cranio-spinal metastasis and improves the overall survival (42). Initial radiotherapy might be associated with improved survival in a subset of patients (43-46), despite of possible devastating neuro-cognitive outcome in the very young.

In conclusion, we herein have presented fifteen cases of $\mathrm{AT} / \mathrm{RT}$ that we have encountered at our center, including 2 cases with exceptional intraventricular location, and 3 cases with unusual growth patterns. INI-1 immunostain should be performed on all CNS embryonal tumors encountered in infants and young children less than 5 years of age, showing malignant small cells simulating CNSPNET/ medulloblatoma, including lesions with favourable histopathologic features such as nodular medulloblastoma, even in the absence of detectable rhabdoid cells. The proper diagnosis of AT/RT is important for providing the appropriate intensive treatment for these patients.

\section{REFERENCES}

1. Judkins AR, Eberhart CG, Wesseling P. Atypical teratoid / rhabdoid tumor. In Louis DN, Ohgaki H, Wiestler OD, Canavee $\mathrm{WK}$, editors. WHO classification of tumours of the central nervous system. Lyon: IARC; 2007. 147-9.

2. Burger PC, Yu IT, Tihan T, Friedman HS, Strother DR, Kepner JL, Duffner PK, Kun LE, Perlman EJ. Atypical teratoid/rhabdoid tumor of the central nervous system: A highly malignant tumor of infancy and childhood frequently mistaken for medulloblastoma: A pediatric oncology group study. Am J Surg Pathol. 1998;22:1083-92.

3. Meyers SP, Khademian ZP, Biegel JA, Chuang SH, Korones DN, Zimmerman RA. Primary intracranial atypical teratoid/rhabdoid tumors of infancy and childhood: MRI features and patient outcomes. AJNR Am J Neuroradiol. 2006;27:962-71.

4. Biggs PJ, Garen PD, Powers JM, Garvin AJ. Malignant rhabdoid tumor of the central nervous system. Hum Pathol. 1987;18:332-7.

5. Biegel JA, Rorke LB, Packer RJ, Emanuel BS. Monosomy 22 in rhabdoid or atypical tumors of the brain. J Neuosurg. 1990;73: 710-4.

6. Bhattacharjee M, Hicks J, Langford L, Dauser R, Strother D, Chintagumpala M, Horowitz M, Cooley L, Vogel H. Central nervous system atypical teratoid/rhabdoid tumors of infancy and childhood. Ultrastruct Pathol.1997;21:369-78.

7. Rorke LB, Packer RJ, Biegel JA. Central nervous system atypical teratoid/rhabdoid tumors of infancy and childhood: Definition of an entity. J Neurosurg. 1996;85:56-65.

8. Biegel JA, Zhou JY, Rorke LB, Stenstrom C, Wainwright LM, Fogelgren B. Germ-line and acquired mutations of INI-1 in atypical teratoid and rhabdoid tumors. Cancer Res. 1999; 59:74-9.

9. Judkins AR, Mauger J, Ht A, Rorke LB, Biegel JA. Immunohistochemical analysis of hSNF5/INI1 in pediatric CNS neoplasms. Am J Surg Pathol. 2004;28:644-50.

10. Tsai CY, Wong TT, Lee YH, Chao ME, Lin SC, Liu DJ, Liang ML, Wang HW, Ho DM. Intact INI1 gene region with paradoxical loss of protein expression in AT/RT: Implications for a possible novel mechanism associated with absence of INI1 protein immunoreactivity. Am J Surg Pathol. 2012;36:128-33. 
11. Hasselblatt M, Gesk S, Oyen F, Rossi S, Viscardi E, Giangaspero F, Giannini C, Judkins AR, Frühwald MC, Obser T, Schneppenheim R, Siebert R, Paulus W. Nonsense mutation and inactivation of SMARCA4 (BRG1) in an atypical teratoid/rhabdoid tumor showing retained SMARCB1 (INI1) expression. Am J Surg Pathol. 2011;35:933-5.

12. Haberler C, Laggner U, Slavc I, Czech T, Ambros IM, Ambros PF, Budka H, Hainfellner JA: Immunohistochemical analysis of INI-1 protein in malignant pediatric cns tumors: Lack of INI-1 in atypical teratoid/rhabdoid tumors and in a fraction of primitive neuroectodermal tumors without rhabdoid phenotype. Am J Surg Pathol. 2006;30:1462-8.

13. Hilden JM, Meerbaum S, Burger P, Finlay J, Janss A, Scheithauer BW, Walter AW, Rorke LB, Biegel JA. Central nervous system atypical teratoid/rhabdoid tumor: Results of therapy in children enrolled in a registry. J Clin Oncol. 2004;22:2877-84.

14. Lafay-Cousin L, Hawkins C, Carret AS, Johnston D, Zelcer S, Wilson B, Jabado N, Scheinemann K, Eisenstat D, Fryer C, Fleming A, Mpofu C, Larouche V, Strother D, Bouffet E, Huang A. Central nervous system atypical teratoid rhabdoid tumours: the Canadian Paediatric Brain Tumour Consortium experience. Eur J Cancer. 2012;48:353-9.

15. Cecen E, Gunes D, Uysal KM, Yuceer N, Ozer E. Atypical teratoid/ rhabdoid tumor in an infant conceived by in vitro fertilization. Childs Nerv Syst. 2010;26:263-6.

16. Cheng YC, Lirng JF, Chang FC, Guo WY, Teng MM, Chang CY, Wong TT, Ho DM. Neuroradiological findings in atypical teratoid/rhabdoid tumor of the central nervous sytem. Acta Radiol. 2005;46:89-96.

17. Koral K, Gargan L, Bowers DC, Gimi B, Timmons CF, Weprin B, Rollins NK. Imaging characteristics of atypical teratoid-rhabdoid tumor in children compared with medulloblastoma. AJR Am J Roentgenol. 2008;190:809-14.

18. Bull JG, Saunders DE, Clark CA. Discrimination of paediatric brain tumours using apparent diffusion coefficient histograms. Eur Radiol. 2012;22:447-57.

19. Donovan DJ, Smith AB, Petermann GW. Atypical teratoid/ rhabdoid tumor of the velum interpositum presenting as a spontaneous intraventricular hemorrhage in an infant: Case report with long-term survival. Pediatr Neurosurg. 2006;42:18792.

20. Inenaga C, Toyoshima Y, Mori H, Nishiyama K, Tanaka R, Takahashi $\mathrm{H}$. A fourth ventricle atypical teratoid/rhabdoid tumor in an infan. Brain Tumor Pathol. 2003;20:47-52.

21. Gessi M, Giangaspero F, Pietsch T. Atypical teratoid/rhabdoid tumors and choroid plexus tumors: When genetics "surprise" pathology. Brain Pathol. 2003;13:409-14.

22. Schittenhelm J, Nagel C, Meyermann R, Beschorner R. Atypical teratoid/rhabdoid tumors may show morphological and immunohistochemical features seen in choroid plexus tumors. Neuropathology. 2011;31:461-7.

23. Fleming AJ, Hukin J, Rassekh R, Fryer C, Kim J, StemmerRachamimov A, Birks DK, Huang A, Yip S, Dunham C. Atypical teratoid rhabdoid tumors (ATRTs): The British Columbia's Children's Hospital's experience, 1986-2006. Brain Pathol. 2012;22:625-35.
24. Ertan Y, Sezak M, Turhan T, Kantar M, Erşahin Y, Mutluer S, Vergin C, Oniz H, Akalin T. Atypical teratoid/rhabdoid tumor of the central nervous system: Clinicopathologic and immunohistochemical features of four cases. Childs Nerv Syst. 2009;25:707-11.

25. Utsuki S, Oka H, Tanaka S, Kondo K, Tanizaki Y, Fujii K. Importance of re-examination for medulloblastoma and atypical teratoid/rhabdoid tumor. Acta Neurochir (Wien). 2003;145:6636.

26. Lee MC, Park SK, Lim JS, Jung S, Kim JH, Woo YJ, Lee JS, Kim HI, Jeong MJ, Choi HY. Atypical teratoid/rhabdoid tumor of the central nervous system: Clinico-pathological study. Neuropathology. 2002;22:252-60.

27. Dufour C, Beaugrand A, Le Deley MC, Bourdeaut F, André N, Leblond P, Bertozzi AI, Frappaz D, Rialland X, Fouyssac F, Edan C, Grill J, Quidot M, Varlet P. Clinicopathologic prognostic factors in childhood atypical teratoid and rhabdoid tumor of the central nervous system: A multicenter study. Cancer. 2012;118:3812-21.

28. Ogino S, Cohen ML, Abdul-Karim FW. Atypical teratoid/rhabdoid tumor of the CNS: cytopathology and immunohistochemistry of insulin-like growth factor-II, insulin-like growth factor receptor type 1, cathepsin D, and Ki-67. Mod Pathol. 1999;12:379-85.

29. Deisch J, Raisanen J, Rakheja D. Immunohistochemical expression of embryonic stem cell markers in malignant rhabdoid tumors. Pediatr Dev Pathol. 2011;14:353-9.

30. Birks DK, Kleinschmidt-DeMasters BK, Donson AM, Barton VN, McNatt SA, Foreman NK, Handler MH. Claudin 6 is a positive marker for atypical teratoid/rhabdoid tumors. Brain Pathol. 2010;20:140-50.

31. Antonelli M, Hasselblatt M, Haberler C, Di Giannatale A, Garrè ML, Donofrio V, Lauriola L, Ridola V, Arcella A, Frühwald M, Giangaspero F. Claudin-6 is of limited sensitivity and specificity for the diagnosis of atypical teratoid/rhabdoid tumors. Brain Pathol. 2011;21:558-63.

32. Sullivan LM, Yankovich T, Le P, Martinez D, Santi M, Biegel JA, Pawel BR, Judkins AR. Claudin- 6 is a nonspecific marker for malignant rhabdoid and other pediatric tumors. Am J Surg Pathol. 2012;36:73-80.

33. Chiou SH, Kao CL, Chen YW, Chien CS, Hung SC, Lo JF, Chen YJ, Ku HH, Hsu MT, Wong TT. Identification of CD133-positive radioresistant cells in atypical teratoid/rhabdoid tumor. PLoS One. 2008;3:e2090.

34. Varlet P, Beaugrand A, Lacroix L, Lequin D, Pierron G, Puget S, Negretti L, Boddaert N, Grill J, Dufour C. Atypical teratoid rhabdoid tumor mimicking beta-catenin-positive nodular medulloblastoma. Acta Neuropathol. 2011;121:429-30.

35. Franke FE, Schachenmayr W, Osborn M, Altmannsberger M. Unexpected immunoreactivities of intermediate filament antibodies in human brain and brain tumors. Am J Pathol. 1991;139:67-79.

36. Woehrer A, Slavc I, Waldhoer T, Heinzl H, Zielonke N, Czech T, Benesch M, Hainfellner JA, Haberler C; Austrian Brain Tumor Registry. Incidence of atypical teratoid/rhabdoid tumors in children: A population-based study by the Austrian Brain Tumor Registry, 1996-2006. Cancer. 2010;116:5725-32. 
37. Hasselblatt M, Oyen F, Gesk S, Kordes U, Wrede B, Bergmann M, Schmid H, Frühwald MC, Schneppenheim R, Siebert R, Paulus W. Cribriform neuroepithelial tumor (CRINET): a nonrhabdoid ventricular tumor with INI1 loss and relatively favorable prognosis. J Neuropathol Exp Neurol. 2009;68:1249-55.

38. Ho DM, Hsu CY, Wong TT, Ting LT, Chiang H. Atypical teratoid/ rhabdoid tumor of the central nervous system: A comparative study with primitive neuroectodermal tumor/medulloblastoma. Acta Neuropathol. 2000;99:482-8.

39. Finkelstein-Shechter T, Gassas A, Mabbott D, Huang A, Bartels U, Tabori U, Janzen L, Hawkins C, Taylor M, Bouffet E. Atypical teratoid or rhabdoid tumors: improved outcome with high-dose chemotherapy. J Pediatr Hematol Oncol. 2010;32:e182-6.

40. Chi SN, Zimmerman MA, Yao X, Cohen KJ, Burger P, Biegel JA, Rorke-Adams LB, Fisher MJ, Janss A, Mazewski C, Goldman S, Manley PE, Bowers DC, Bendel A, Rubin J, Turner CD, Marcus KJ, Goumnerova L, Ullrich NJ, Kieran MW. Intensive multimodality treatment for children with newly diagnosed CNS atypical teratoid rhabdoid tumor. J Clin Oncol. 2009;27:385-9.

41. Gardner SL, Asgharzadeh S, Green A, Horn B, McCowage G, Finlay J. Intensive induction chemotherapy followed by high dose chemotherapy with autologous hematopoietic progenitor cell rescue in young children newly diagnosed with central nervous system atypical teratoid rhabdoid tumors. Pediatr Blood Cancer. 2008;51:235-40.
42. Athale UH, Duckworth J, Odame I, Barr R. Childhood atypical teratoid rhabdoid tumor of the central nervous system: a metaanalysis of observational studies. J Pediatr Hematol Oncol. 2009; 31:651-63.

43. Buscariollo DL, Park HS, Roberts KB, Yu JB. Survival outcomes in atypical teratoid rhabdoid tumor for patients undergoing radiotherapy in a Surveillance, Epidemiology, and End Results analysis. Cancer. 2012;118:4212-9.

44. Chen YW, Wong TT, Ho DM, Huang PI, Chang KP, Shiau CY, Yen $\mathrm{SH}$. Impact of radiotherapy for pediatric CNS atypical teratoid/ rhabdoid tumor (single institute experience). Int J Radiat Oncol Biol Phys. 2006;64:1038-43.

45. Pai Panandiker AS, Merchant TE, Beltran C, Wu S, Sharma S, Boop FA, Jenkins JJ, Helton KJ, Wright KD, Broniscer A, Kun LE, Gajjar A. Sequencing of local therapy affects the pattern of treatment failure and survival in children with atypical teratoid rhabdoid tumors of the central nervous system. Int J Radiat Oncol Biol Phys. 2012;82:1756-63.

46. Squire SE, Chan MD, Marcus KJ. Atypical teratoid/rhabdoid tumor: The controversy behind radiation therapy. J Neurooncol. 2007;81:97-111. 